\title{
Anthropometric craniofacial pattern profiles in microcephaly
}

\author{
Ghada M.H. Abdel-Salam, ${ }^{1}$ Gyula Gyenis, ${ }^{2}$ \\ Andrew E. Czeizel ${ }^{3}$ \\ ${ }^{1}$ Department of Human Genetics, National Research Centre, Tahrir street, \\ Dokki, Cairo, Egypt; E-mail: ghasala@hotmail.com \\ ${ }^{2}$ Department of Biological Anthropology, Eötvös Loránd University, \\ Pázmány Péter sétány $1 / C$, Budapest, Hungary \\ ${ }^{3}$ Foundation for the Community Control of Hereditary Diseases, \\ Bolgárkerék u. 3, Budapest, Hungary; E-mail: czeizel@mail.InterWare.hu
}

\begin{abstract}
Craniofacial measurements were taken in 60 cases presenting with microcephaly. The cases were classified etiologically and morphologically and the latter was further subclassified. Craniofacial pattern profiles, cranial capacity, and the pattern variability index were calculated and compared with normal Hungarian controls of the same age and sex. In addition, correlation analysis between cranial capacity and IQ was done. Our results show significant similarity of the craniofacial pattern profiles between isolated microcephaly (IMC) and multiple microcephaly (MMC), and between primary microcephaly (PMC) and secondary microcephaly (SMC). The pattern variability index of the microcephalic cases was 4.77 . There was no correlation between cranial capacity and IQ in the microcephalic patients.
\end{abstract}

KEY WORDS microcephaly, cranial capacity, IQ

Prz. Antropol. - Anthropol. Rev. (2002), vol. 65, pp. 65-74, Figs. 4, Tables 2. ISBN 838696-80-6, ISSN 0033-2003

Microcephaly (MC) is not a specific diagnostic sign, but a group of conditions that have one common feature small head circumference - which may stem from heterogeneous genetic as well as environmental etiologies. Microcephaly is not distinguished by a characteristic facial appearance except that of reduced size of the head. However, few anthropometric craniofacial studies reported deal with this subject. Furthermore, it is very difficult to make a general statement about the impact of the small head size on IQ.

According to NELLHAUS [1968], microcephaly is defined as a head circumference of 2 standard deviations below the average for age, sex and 'race'. OPITZ and HOLT [1990] classified primary MC according to head circum- 
ference measures at birth and considered all cases that develop MC after that time to be acquired. However, others denied the value of head circumference at birth and classified MC into primary and secondary. The former (PMC) is defined as it has a genetic basis, and it is diagnosed after the exclusion of all the environmental factors and it may be evident in the first months of life, while the latter (SMC) could stem from various environmental causes [HOLMES et al. 1972, QAZI and REED 1973, SCHEFFER et al. 1992]. Microcephaly could be termed genetic when talking about primary MC [SCHEFFER et al. 1992]. In addition, $\mathrm{MC}$ is also known as isolated (non-syndromal) when there are no associated anomalies except those that can be attributed to the small size of the brain, i.e., mental retardation and epilepsy, or multiple (syndromal) when there is an additional developmental disorder occurring in an organ or tissues other than the brain [COHEN et al. 1996].

This study presents the craniofacial pattern profiles, as well as the pattern variability index of the various phenotypes of microcephaly, in order to assess whether these measurements are useful for determination of the etiology of microcephaly, to compare the craniofacial characteristics according to different classifications (etiology and morphology), and to find out a correlation between microcephalic cranial capacity and IQ.

\section{Materials and methods}

309 patients affected with either IMC or MMC were registered at the Hungarian Congenital Abnormality Registry (HCAR) from 1980 to 1996. The HCAR is based on a national registry of cases with congenital abnormalities. Notification of congenital abnormalities is mandatory for medical doctors, particularly obstetricians and pediatricians. Patients with $\mathrm{MC}$ were selected from the data set of the HCAR and then invited (with their parents) to the Department of Human Genetics and Teratology of the National Public Health Institute for personal evaluation and check-up examination. In addition, we evaluated 42 cases in the residential institutes of mentally subnormal children (National Methodological Institute of Hygienic Children's Home, Pető Institute and Institute of Children with Mental Subnormality in Budapest). Finally, 16 cases with MC who visited the Genetic Counselling Clinic in Budapest during the period January 1997 - January 1999 were also examined and evaluated.

Microcephaly was defined if there were at least 3 successive measurements taken in the first year of life and 2 successive measurements taken after the first year and if their maximal head circumference fell more than 2 SD below the mean of the same age and sex using two Hungarian samples of EIBEN et al. [1992] and JOUBERT et al. [1993]. These criteria led to the exclusion of many cases diagnosed at birth as microcephalic, since successive head measurements in the first year of life proved that these cases showed catching up of the head growth and attainment of normality by the first year of life. In addition, we excluded cases with craniostenostosis, Down syndrome, Rubinstein-Taybi syndrome (these cases have special craniofacial patterns), microcephaly due to systemic disease such as congenital cardiovascular malformations 
or malabsorption (these diseases can cause microcephaly but may be reversible). We also excluded cases with severe contracture deformity, which enabled us to put the patient in the correct position to take accurate cranial measurements.

Of the 60 cases fulfilling the selection criteria of our study, 27 were males $(45 \%)$ and 33 females (55\%). At the time of examination, the age of the cases ranged from 1 to 27 years old (mean $13.07 \pm 1.17 \mathrm{yrs}$ ). We then evaluated the 60 MC cases, which were classified etiologically into primary microcephaly (PMC) and secondary microcephaly (SMC), and morphologically into isolated (IMC) and multiple congenital abnormality associated with microcephaly (MMC).

Detailed prenatal, perinatal and postnatal histories were obtained, and patients were diagnosed as having PMC if they have fulfilled most of the following criteria: (1) history of consanguinity; (2) affected sibs; (3) history of mental retardation and/or microcephaly in the family; (4) normal pregnancy history; (5) normal delivery history; (6) negative results of serology for connatal infections; (7) negative screening test for PKU and hypothyroidism; and (8) excluding the environmental factors (trauma, drug ingestion etc.). Conversely, SMC was suggested to be present if the patients showed implicated environmental factors.

All of the patients were closely physically and clinically examined with special emphasis on the congenital abnormalities and the neurological status by two of the authors who, in addition, retrospectively reviewed all the hospital medical records. Morphological classi- fication of MC was based on: (1) the clinical manifestations; (2) neurological evaluation; (3) CT and or MRI picture; (4) chromosomal study. Regardless of etiology, we classified microcephaly morphologically into two forms (see Fig. 1):

1) Isolated microcephaly (IMC): where there were no associated anomalies except those that can be attributed to the small size of the brain.

2) Multiple microcephaly (MMC): which is defined where there is an additional developmental disorder occurring in an organ or tissues other than the brain.

IMC and MMC were further subclassified as is shown on the graph (Fig. 1).

Intelligence quotient (IQ) and/or developmental quotient (DQ) were tested in all the patients using the BudapestBinet test and the Popper-Szondy scale (the Hungarian standard of development during infancy and early childhood). The IQ was then classified according to the WHO classification into: (1) normal: 85-100; (2) subnormal (but still educable): 84-70; (3) mild: 51-69; (4) moderate: $36-50$; (5) severe: $21-35$; (6) profound: $0-20$.

A series of anthropometric craniofacial measurements were taken for each case according to the method of FARKAS [1981]. The anthropometric traits used in this study were chosen to comprise measurements that represent the head breadth $(e u-e u)$, the head length $(g-o p)$, the facial height $(n-g n)$ the bizygomatic width $(z y-z y)$ and the head circumference. Standard anthropometric equipment, including GPM sliding and spreading, blunt ended calipers and a steel tape measure were used. In the data collection and measurements, recording was done to the nearest $0.5 \mathrm{~mm}$. 


\begin{tabular}{|c|c|}
\hline $\begin{array}{l}\text { Isolated microcephaly (IMC) } \\
\end{array}$ & Multiple microcephaly (MMC) \\
\hline $\begin{array}{l}\text { Natural } \\
\text { was defined as microcephaly with normal } \\
\text { intelligence and these cases have special } \\
\text { facial features (RIZZO and PAVONE 1995, } \\
\text { ABDEL-SALAM and CZEIZEL 2000). }\end{array}$ & $\begin{array}{l}\text { As a part of well known syndrome } \\
\text { e.g., Smith-Lemlie-Opitz syndrome, } \\
\text { Cohen syndrome, Cornelia de Lange } \\
\text { syndrome, Rett syndrome, etc. }\end{array}$ \\
\hline $\begin{array}{l}\text { Single (pure or simple) } \\
\text { when there is only microcephaly with } \\
\text { mental retardation and /or seizures } \\
\text { (JACKSON } \text { et al. 1998). }\end{array}$ & $\begin{array}{l}\text { As a part of unidentified multiple } \\
\text { congenital abnormalities }\end{array}$ \\
\hline $\begin{array}{l}\text { Sequence } \\
\text { if microcephaly was associated with } \\
\text { cerebral palsy (normal CT picture) } \\
\text { (MITCHELL and BUBDEY 1997, GROSS- } \\
\text { TsUR et al. 1995). }\end{array}$ & $\begin{array}{l}\text { As a part of chromosomal } \\
\text { aberrations syndromes } \\
\text { e.g., Ring } 14 \text { syndrome, } 17 \mathrm{p}+\text {, etc. }\end{array}$ \\
\hline $\begin{array}{l}\text { Complex } \\
\text { when the microcephaly is due to } \\
\text { congenital brain malformation e.g., } \\
\text { porencephaly, pachygyria and etc., and it } \\
\text { was presented with microcephaly with } \\
\text { tetraplegia (BARKOVICH et al. 1996). }\end{array}$ & $\begin{array}{l}\text { Due to teratogens } \\
\text { e.g., alcohol, solvents, rubella, } \\
\text { cytomegalovirus, toxoplasmosis, etc. }\end{array}$ \\
\hline
\end{tabular}

Fig. 1. The proposed morphological oriented classification of the microcephaly.

Cranial capacity (only for adults; $N=20$ ) was calculated by the method of Pearson (see MARTIN, SALLER [1957]) and morphological facial index and cephalic index were calculated by the Martin and Saller's formulae.
The age- and sex-matched control data (normal population) were obtained from the published measurements performed by EIBEN [1967] on healthy Hungarians (boys and girls 1-19-yearold; $N=1,656)$. For each craniofacial mea- 
surement of each case, a standardized $z$-score (standard deviation units) was calculated as the difference between the measurement and mean for age and sex divided by the age appropriate standard deviation. Thus, the effects of age and sex are eliminated [GARN et al. 1985]. Then the pattern variability $\sigma_{z}$ (standard deviation of the set of $z$-scores for each individual) was calculated to show the extent of dysmorphogenesis among the microcephalic cases. Actual values of $\sigma_{z}$ ranged from near the theoretical minimum of 0.0 through 1.27 for the most extreme of the normal individuals and 2.0 and above for malformation conditions.

For statistical analysis of the data, SPSS software (version 6) was used. Simple linear regression and correlation coefficient $\left(r_{z}\right)$ analysis was computed from paired $z$-scores of two pattern profiles to evaluate the similarity between different pattern profiles, which provides a numerical indication of the similarity of any two patterns. All the tests were two-sided and $p$ values of 0.05 were considered significant. In addition, the t-test was used to compare the values of all the measurements. Correlation analysis was then done to show interdependence between cranial capacity and IQ.

\section{Results}

\section{General features}

The head circumference of the patients ranged from 3 to $8.6 \mathrm{SD}$ below the mean. Seven cases (11.7\%) showed affected family members (sibs and other relatives) either with the same genetic disorder or with other genetic abnormalities and/or mental subnormalities, including one brother and sister pair from consanguinous parents. None of the parents had a microcephalic head. Congenital microcephaly was present in 43 cases $(71.7 \%)$ while 17 cases (28.3\%) developed microcephaly in the first months of life. According to the etiological classification, 41 cases $(68.3 \%)$ had PMC while 19 cases $(31.7 \%)$ had SMC. The number of cases classified according to the morphological classification is shown in Table 1.

Table 1. Number of cases and pattern variability indices of cases with microcephaly according to the morphological classification

\begin{tabular}{lcc}
\hline & Number of cases & Pattern variability index \\
\hline Isolated microcephaly & Total $=32(53.3 \%)$ & 4.60 \\
Natural & 1 & 5.11 \\
Single & 8 & 4.61 \\
Sequence & 12 & 4.22 \\
Complex & 11 & 4.59 \\
Multiple microcephaly & Total $=28(46.7 \%)$ & 5.03 \\
Well identified syndromes & 14 & 5.34 \\
Unidentified syndromes & 7 & 5.20 \\
Chromosomes & 3 & 6.58 \\
Teratogens & 4 & 3.01 \\
\hline
\end{tabular}


While $58.3 \%(N=35)$ of the patients showed normal tone and reflexes, spastic paraplegia or quadriplegia were evident in $41.7 \%$ of the cases $(N=25)$. The mean IQ of the cases was $33.8 \pm 2.9$, with a range of 4 to 85 . CT and/or MRI imaging showed abnormalities in $45.9 \%$ of the cases $(N=27)$. Chromosomal analysis showed structural abnormalities (one with ring 14 , one with $21 \mathrm{p}+$ and one with $7 \mathrm{p}+)$ in 3 cases $(5 \%)$.

\section{Craniofacial pattern profiles}

All the craniofacial profiles display $z$-scores on the vertical axis and craniofacial traits on the horizontal axis. The profiles of cases with various types of MC are fairly similar (Figs. 2, 3), since the correlation coefficients $\left(r_{z}\right)$ were $0.863(p=0.01)$ and $0.967(p=0.0001)$ in those with primary and secondary microcephaly and cases with isolated and multiple microcephaly, respectively. The differences between the craniofacial measurements in cases with MC according to various classifications are presented in Table 2. Cases with secondary MC presented with higher craniofacial values than those of primary MC, except in respect of the cephalic index (Fig. 2 and Table 2). The isolated MC cases also show higher values in the majority of the measurements and indices than the multiple MC cases (Figs. 3, 4 and Table $2)$. There was no correlation between cranial capacity and the head circumference $(p=0.07)$ or between cranial capacity and IQ $(p=0.3)$ at the time of examination.

The pattern variability index $\sigma_{z}$ of the microcephalic cases was 4.77. It was slightly higher in males than females (4.84 and 4.71, respectively). The pattern variability index according to morphological classification is shown in Table 1.

Table 2. Differences between the craniofacial measurements in cases with microcephaly according to various classifications

\begin{tabular}{lcccccc}
\hline & IMC & MMC & $P$ value & PMC & \multicolumn{2}{c}{ SMC } \\
$N=32$ & $N=28$ & & $N=41$ & \multicolumn{2}{c}{$P$ value } \\
\hline$g-o p$ & -1.6 & -2.7 & $0.02^{*}$ & -2.4 & -1.5 & 0.09 \\
eu-eu & -4.6 & -2.6 & $0.00^{*}$ & -4.6 & -4.5 & -0.75 \\
$n-g n$ & -1.2 & -1.7 & 0.13 & -1.6 & -1.0 & 0.16 \\
$z y-z y$ & -3.5 & -3.5 & 0.90 & -3.5 & -3.3 & 0.68 \\
Facial index & 1.4 & 0.8 & 0.20 & 1.0 & 1.6 & 0.29 \\
Cephalic index & -2.7 & -1.8 & 0.06 & -2.1 & -2.6 & 0.32 \\
Cranial capacity & 1050 & 1126 & 0.09 & 1066 & 1150 & 0.06 \\
IQ & 28.9 & 39.3 & 0.07 & 37.3 & 29.2 & 0.07 \\
\hline
\end{tabular}

* statistical significance.

Abbreviations: IMC - isolated microcephaly; MMC - multiple congenital abnormalities associated with microcephaly, PMC primary microcephaly, SMC - secondary microcephaly. 


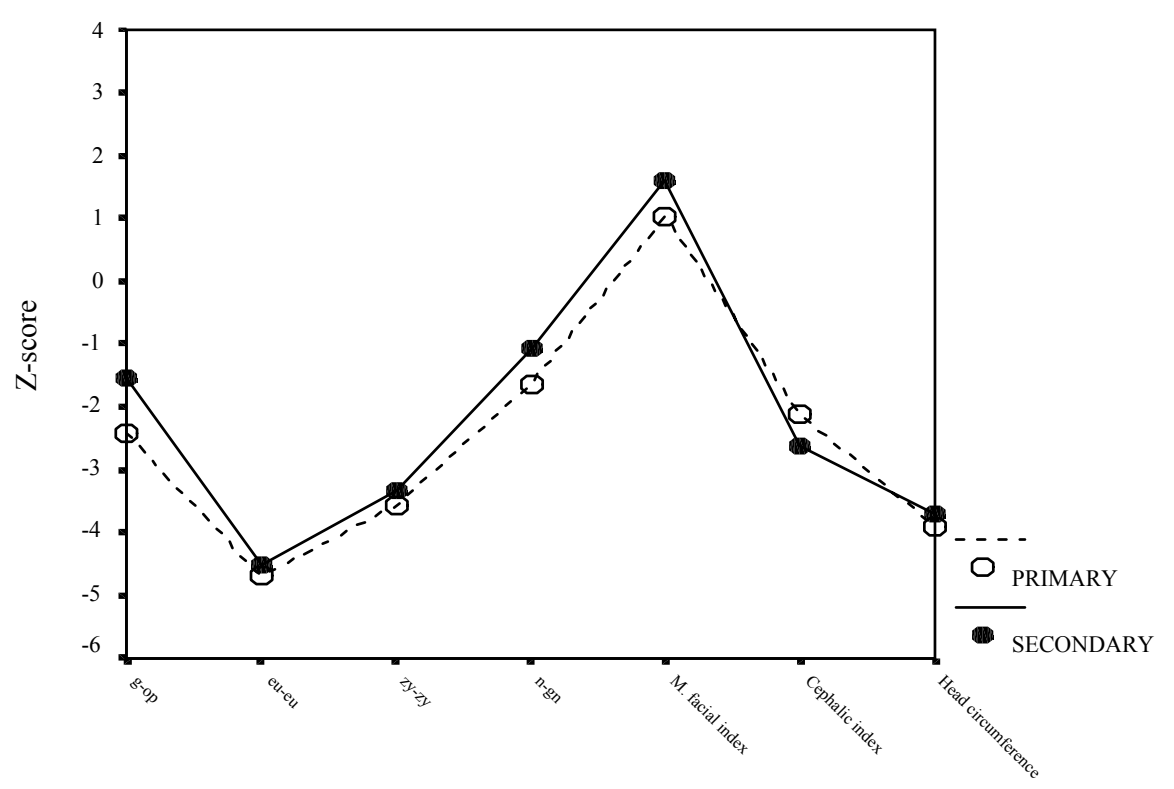

Fig. 2. Craniofacial pattern profile which compares cases of primary microcephaly versus secondary. The two patterns are strikingly similar $(r=0.86 ; p=0.012)$.

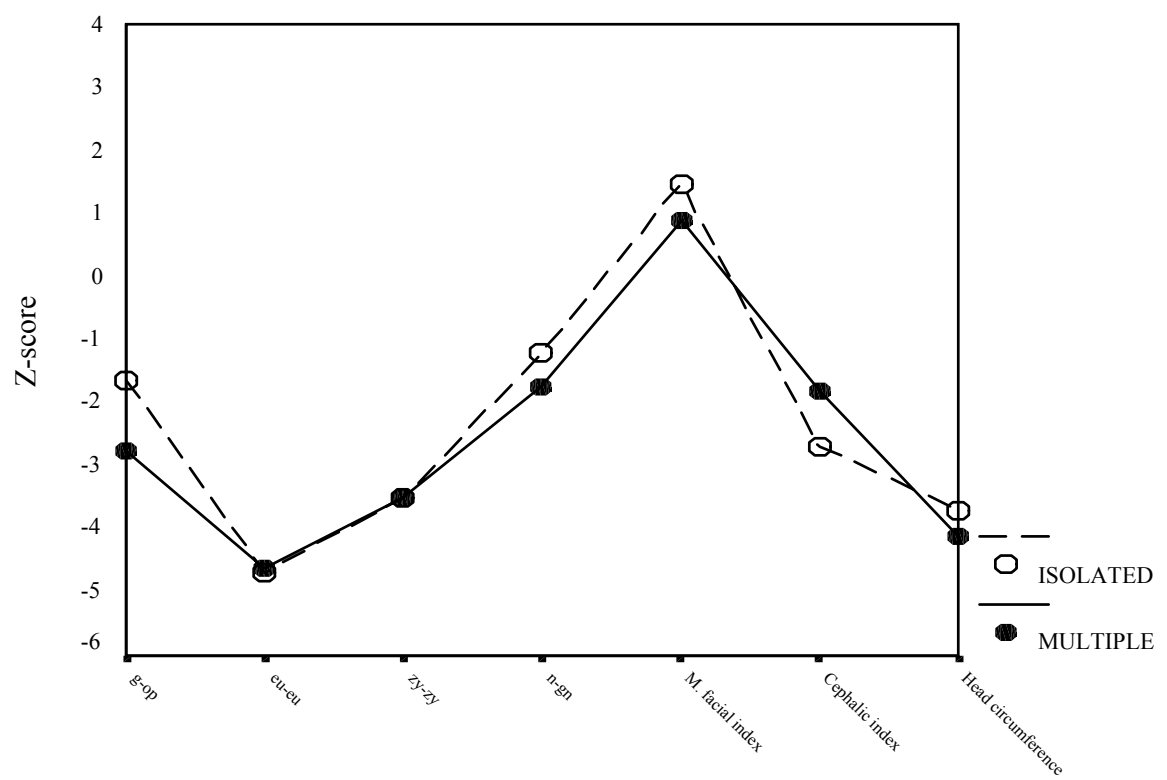

Fig. 3. Craniofacial pattern profile which compares cases of isolated microcephaly versus multiple. The two patterns are strikingly similar $(r=0.96 ; p=0.000)$. 


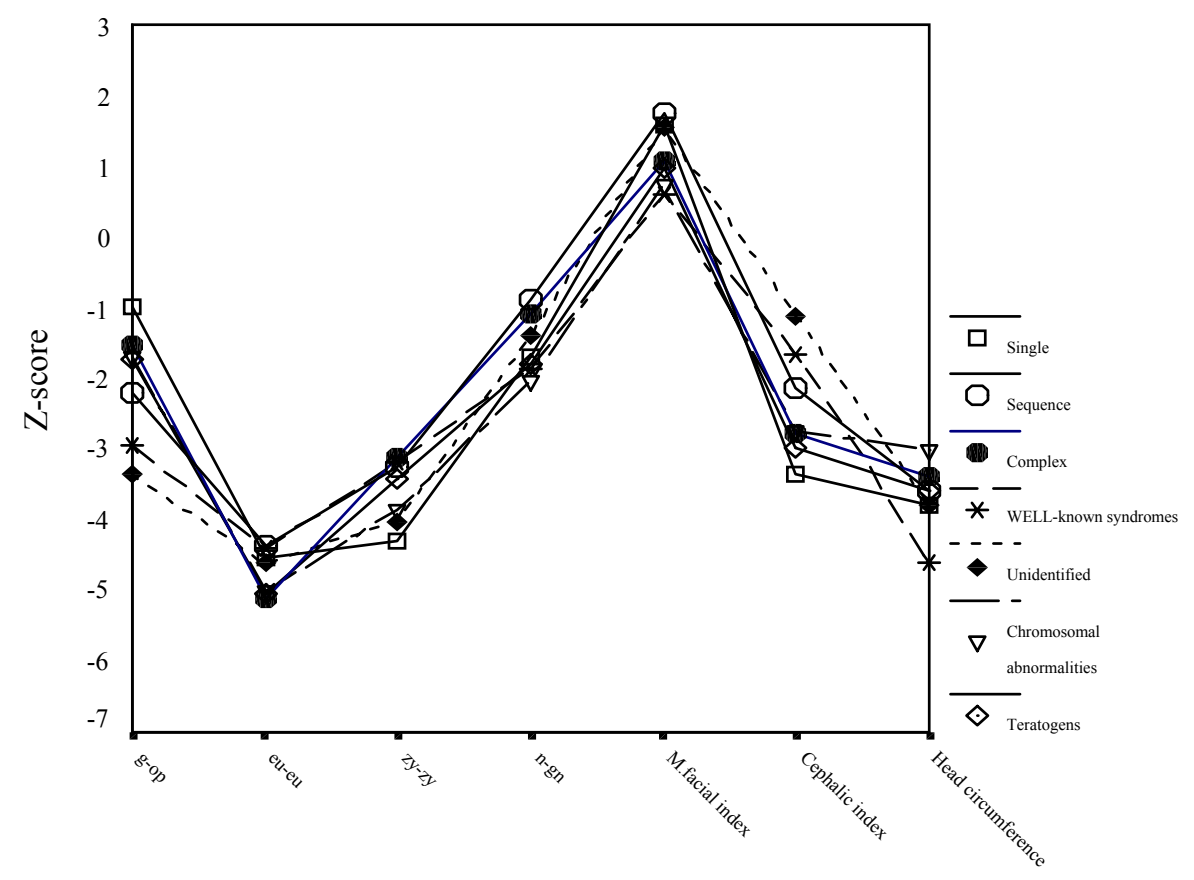

Fig. 4. Craniofacial pattern profile which compares the subgroups of the microcephalic cases according to morphological classification.

\section{Discussion}

This study described the craniofacial profile in 60 cases with $\mathrm{MC}$ although they were etiologically (primary or secondary) or morphologically (isolated or multiple) different. Our data have shown that regardless of etiology or morphology, cases with MC presented with the same craniofacial pattern. Cases with primary and secondary microcephaly showed lower values when compared to the control, but these values are lower in primary than secondary microcephaly. Conversely, cases with secondary microcephaly showed a smaller difference compared to the control. It is noteworthy that the morphological facial index showed the smallest difference compared to the control. Cases with MC are described in the literature characterized by a receding forehead, often parallel with a slanting nose, receding chin and normal size face [BARAITSER 1982], but there is no agreement among authors about the application of these criteria to the diagnosis of microcephaly [SCHEFFER et al. 1992].

Generally, the pattern variability index expresses the degree of dysmorphogenesis as a single number. Specific patterns are described in many syndromes, being 5.20 in Down syndrome [ALLANSON et al. 1993], 2.03 in Apert syndrome, 1.71 in acrocephaly syndactyly syndrome, 1.48 in Crouzon syndrome [WARD et al. 1998], 1.41 in Sotos syndrome [ALLANSON and COLE 1996] and 
1.21 in Beckwith-Wiedemann syndrome [HUNTER and ALLANSON 1993]. In general, our microcephalic cases showed a pattern variability index of 4.77 . This pattern exhibited a slight difference among males and females probably because of the striking similarity of the craniofacial pattern in cases with $\mathrm{MC}$ in both sexes and in different groups according to morphological classification.

This study has documented that the cranial capacity of cases with microcephaly did not correlate with IQ or head circumference, which is strong evidence for the hypothesis that IQ is determined neither by cranial capacity nor the degree of MC. This conclusion has also been arrived at in many prospective studies of microcephaly [QAZI and REED 1973, DOLK 1991]. However, the result of this study requires further investigations into microcephalics to determine whether it is a general characteristic of MC or merely a chance-effect.

\section{Acknowledgements}

We are extremely grateful to Professor Otto Eiben for his guidance and training of one of the authors (GMH A-S) in the landmark identification portion of this study, and in providing access to the normative craniofacial data from his previous studies.

\section{References}

AbDel-Salam G.M.H., A.E. Czeizel, 2000, The second unrelated case with isolated microcephaly and normal intelligence (Microcephalia vera), Clinic. Dysmorph., 2, 155-156

Allanson J.E., P. O'Hara, L.G. FARKas, R.C. NAIR, 1993, Anthropometric craniofacial pattern profiles in Down syndrome, Am. J. Med. Genet., 47, 748-752
Allanson J.E., T.R.P. Cole, 1996, Sotos syndrome: Evolution of facial phenotype subjective and objective assessment, Am. J. Med. Genet., 65, 13-20

BARKOVICH A.J., R.I. KUZNIECKY, W.B. DOBYNS, G.D. JACKSON, L.E. BECKER, P.A. EVRARD, 1996, Classification scheme for malformations of cortical development, Neuropediatr., 27, 59-63

BARAITSER M. 1982, The genetics of neurological disorders, Oxford Univ. Press, Oxford

Cohen T., M. Zeitune, J. Mcgillivray, J. Hall, L.N. LynN, C.E. Aston, A. ChaKravarti, 1996, Segregation analysis of microcephaly, Am. J. Med. Genet., 65, 226-234

DolK H., 1991, The predictive value of microcephaly during the first year of life for mental retardation at seven years, Dev. Med. Child Neurol., 33, 974-983

EIBEN O.G., 1967, Gyermekek fej-és arcméreteinek változásai nyugatmagyarországi vizsgálatok alapján (Changes of head and face dimensions of children on the basis of WestHungarian surveys), Anthr. Közlem., 11, 165-185

Eiben O.G., M. FARKAS, I. KÖRMENDY, A. PAKSY, Z. VARGA Teghze-Gerber, P. VARGHA, 1992, A budapesti longitudinális növekedésvizsgálat 1970-1988 (The Budapest Longitudinal Growth Study 1970-1988), Humbiol. Budapest., 23, 208

FARKAS L.G., 1981, Anthropometry of the Head and Face in Medicine, New York, Elsevier

GARN S.M., M. LAVELle, B.H. SMITH, 1985, Quantification of dysmorphogenesis: Pattern variability index $z$, Am. J. Radiol., 144, 365369

Gross-Tsur V., A. Joseph, G. Blinder, N. AMIR, 1995, Familial microcephaly with severe neurological deficits: A description of five affected siblings, Clinic. Genet., 47, 33-37

Holmes L.B., C. MACK, H.W. Moser, S.S. PANT, S. Halldorsson, B. Matzilevich, 1972, Mental Retardation: An Atlas of Diseases with Associated Physical Abnormalities, New York, MacMillan

Hunter A.G.W., J.E. Allanson, 1993, The changing face and its anthropometric correlates in Beckwith Wiedemann syndrome, Proc. Greenwood Genet. Cen., 12, 29

JaCKSON A.P., D. MChale, D. CAMPBell, H. JAFRI, Y. RASHID, J. MANNAN, G. Karbani, P. Corry, M. Levene, R. Mueller, A. Mark- 
HAm, N. Lench, C. Woods, 1998, Primary autosomal recessive microcephaly (MCPH1) maps to chromosome 8p22-pter, Am. J. Hum. Genet., 63, 541-546

Joubert K., R. Ágfalvi, S. Darvay, 1993, Módszertani összeállitás a 0-6 éves korú gyermekek növekedésének és fejlödésének vizsgálatához (Methods for the examination of the growth and development of the children between 0-6 years of age), Országos Csecsemö és Gyermekegészségügyi Intézet, Budapest

MARTIN R., K. SALLER, 1957, Lehrbuch der Anthropologie, Gustav Fischer Verlag, Stuttgart

Mitchell S., S. Bundey, 1997, Symmetry of neurological signs in Pakistani patients with probable inherited spastic cerebral palsy, Clinic. Genet., 51, 7-14

Nellhaus G., 1968, Head circumference from birth to eighteen years: Practical composite international and interracial graphs, Pediatr., 41, 106-114
OPITZ J.M., M.C. HoLt, 1990, Microcephaly: General considerations and aids to nosology, J. Craniofac. Genet. Develop. Biol., 10, 175-204

QAZI Q.H., T.E. REED, 1973, A problem in diagnosis of primary versus secondary microcephaly, Clin. Genet., 4, 46-52

Rizzo R., L. Pavone, 1995, Autosomal recessive microcephaly in two siblings, one with normal $I Q$ and both with protruding mandible, small ears and curved nose, Am. J. Med. Genet., 59, 421-425

SChefFer I.E., M. BARAitser, J. Wilson, C. GODFREY, E.M. BRETT, 1992, Autosomal recessive microcephaly with severe psychomotor retardation, Neuropediatr., 23, 53-56

WARD, R.E., P.L. JAMISON, L.G. FARKAS, 1998, Craniofacial variability index: A simple measure of normal and abnormal variation in the head and face, Am. J. Med. Genet., 80, 232-240

\section{Streszczenie}

Celem pracy było: (1) zbadanie proporcji mózgowej i twarzowej części głowy u osób z mikrocefalią i określenie stopnia odchyleń tych proporcji od wartości uznawanych za normalne $\mathrm{w}$ populacji oraz (2) zbadanie korelacji między obliczoną pojemnością puszki mózgowej a wskaźnikiem IQ w grupie mikrocefalików. U 60 osobników w wieku 1-27 lat z rozpoznaną mikrocefalią, pochodzących z Węgierskiego Rejestru Wad Wrodzonych, zmierzono długość i szerokość głowy, wysokość i szerokość twarzy oraz obwód głowy. Oznaczono również iloraz inteligencji IQ. Z pomiarów obliczono wskaźniki ilorazowe i pojemność puszki mózgowej. Wartości pomiarów znormalizowano na właściwe dla płci i wieku normy węgierskie. Porównań osób z różnymi postaciami mikrocefalii i z danymi dla osób zdrowych dokonano metodą profili wartości znormalizowanych $z$. Stwierdzono, że profile nie różnią się istotnie między podgrupami z mikrocefalią prostą (IMC) i złożoną (MMC) oraz między podgrupami z mikrocefalią pierwotną (PMC) i wtórną (SMC). Wskaźnik wewnętrznej zmienności kształtu głowy $\sigma_{z} \mathrm{u}$ osób $\mathrm{z}$ mikrocefalią (średnia z odchyleń standardowych znormalizowanych pomiarów głowy osobnika) u badanych osób wynosił średnio 4,77 . U osób tych nieistotny okazał się również współczynnik korelacji między objętością puszki mózgowej i wskaźnikiem inteligencji IQ. 